\title{
Effect of Corrosion Inhibitors on Chromate-free Passivation of Hot-Dip Galvanized Steel
}

\author{
Bo GAO *, Liyang DONG, Guanglin ZHU, Chao GAO, Ganfeng TU \\ School of Metallurgy, Northeastern University, Shenyang 110819, Liaoning province, China \\ cross ref http://dx.doi.org/10.5755/j01.ms.24.3.16330
}

Received 02 October 2016; accepted 31 October 2017

\begin{abstract}
Commercially available passivation methods for white-rust protection of Hot-Dip Galvanized steel have been applied for chromate passivation. However, hexavalent chromium (Cr-VI) is highly toxic and carcinogenic. Therefore, in this paper, we put forth a new means for white-rust protection of Hot-Dip Galvanized steel based on the effects of corrosion inhibitors. In this study, the passivation solution combines the advantages of inorganic salt passivation, silane passivation and resin passivation. The corrosion resistance of the inorganic and organic composite passivation films with corrosion inhibitors was determined by a neutral salt spray test and electrochemical Tafel polarization curves. The surface chemistry of the coatings was monitored by scanning electron microscopy (SEM), X-ray Photoelectron spectroscopy (XPS) and Fourier transform infrared reflection absorption spectroscopy (FTIR). And further studying on the formation mechanism of the passivation film was carried out. The SEM indicated that the top surface of the passivation film was transparent, smooth, uniform and compact. The XPS and FTIR results showed that the passivation film consisted mainly of organic functional groups including- $\left(\mathrm{CH}_{2}\right) \mathrm{n}-,-\mathrm{OH}, \mathrm{N}-\mathrm{H}, \mathrm{C}=\mathrm{O}, \mathrm{C}-\mathrm{Si}, \mathrm{C}-\mathrm{O}-\mathrm{C}, \mathrm{C}-\mathrm{N}, \mathrm{Si}-\mathrm{O}-\mathrm{Si}, \mathrm{Si}-\mathrm{O}-\mathrm{C}$ and so on. The corrosion resistance of passivation film with corrosion inhibitors was significantly improved than that of the passivation film without corrosion inhibitor. After $96 \mathrm{~h}$ of the corrosion test, the corrosion area was found to be less than $5 \%$, which indicated that the passivation film greatly improved the corrosion resistance of the hot-dip galvanized sheet, and exhibited a very good protective effect so that can met some industrial applications.

Keywords: corrosion, hot-dip galvanized steel, chromium free, corrosion inhibitor, passivation.
\end{abstract}

\section{INTRODUCTION}

Hot-Dip Galvanized (HDG) steel is inexpensive and has excellent performance, and it is widely used in automobiles, home appliances, containers, building materials, transportation, energy, and other applications. However, under a hot and humid environment, Hot-Dip Galvanized steel is prone to corrosion and forms white rust; therefore, the Hot-Dip Galvanized steel is usually subjected to a passivation treatment. Chromate passivation is the most widely adopted treatment for HDG steel available in the market. Unfortunately, hexavalent chromium (Cr-VI) is highly toxic, carcinogenic, and causes serious pollution of the environment [1-5]. Therefore, there is a need to develop an inexpensive, environmentally friendly, high performance, and simple thermal passivation technology for zinc coatings.

Current research on this aspect focuses on many strategies such as the use of inorganic free passivation organic chromium free passivation, the organic and inorganic composite chromium free passivation. The properties of an inorganic and organic composite passivation film are better than that of a pure inorganic passivation film or organic passivation film [6-10]. Moreover, the organic and inorganic composite passivation film used for the chromate-free passivation of HDG steel with high corrosion resistance and has become the focus of much attention. For this reason, one of the ways to improve the anticorrosive properties of the hybrid films is with addition of corrosion inhibitors based on inorganic salts as demonstrated [11]. We found that the corrosion resistance of hot dip galvanized sheet could be significantly enhanced by the addition of several different corrosion inhibitors. In this study, we combined the advantages of inorganic salt passivation (titanate passivation, silicate passivation), silane passivation, and resin passivation. Styrene acrylic emulsion, which is made from styrene and acrylate monomer by emulsion copolymerization, was used as the polymer film forming material. The Glycidoxypropiltrimethoxysilane was used for coupling the organic polymer and inorganic filler to enhance its adhesion. Lastly, corrosion inhibitor was added to the solution. When corrosion inhibitors are added, it penetrates into the surface where there is a flaw or where it the material is corroded. It can inhibit the occurrence and development of corrosion and has a certain self-healing action. Finally, the corrosion resistance of this inorganic and organic composite passivation film with corrosion inhibitors was determined.

\section{EXPERIMENTAL PROCEDURE}

HDG steel sheets were supplied by Anshan iron and steel group corporation (in China) in the skin-passed state. The HDG steel sheets were cut prior to the tests to dimensions of $80 \mathrm{~mm} \times 100 \mathrm{~mm} \times 1 \mathrm{~mm}$. Then, the HDG samples were subjected to alkaline cleaning at $65^{\circ} \mathrm{C}$ in

\footnotetext{
* Corresponding author. Tel.: +86-138-8915-3879.

E-mail address: gaob@smm.neu.edu.cn (B. Gao)
} 
order to improve the wettability of the surface, followed by rinsing in deionized water and a drying step. Finally, the samples were dried at $100{ }^{\circ} \mathrm{C}$. In this study, the preparation of the passivation solution was divided into two steps. First, a certain proportion of ammonium metavanadate and fluorine titanate (China, supplied by Sinopharm Chemical Reagent Co., Ltd) were dissolved in $60 \mathrm{wt} \%$ of the volume of deionized water, and ammonia was used to adjust the $\mathrm{pH}$ to 2.2. Then, the Glycidoxypropiltrimethoxysilane was dissolved in $40 \mathrm{wt} . \%$ of the remaining water, following Which the two solutions were mixed to achieve complete miscibility. Then, we added to it a small amount of fatty alcohol polyoxyethylene ether (AEO-7), polyvinyl alcohol (1788), and twelve sodium dodecyl sulfate (K-12) (China, supplied by Sinopharm Chemical Reagent Co., Ltd) to enhance film adhesion. Finally, it was stirred evenly after adding acrylic emulsion and organic phosphate ester polymer and adjustment of the $\mathrm{pH}$ to 5.03. Samples were coated with the passivation solution and cured in a drying oven at $150{ }^{\circ} \mathrm{C}$ for $1 \mathrm{~min}$. Table 1 summarized the features and characteristics of the different pre-treated samples and the content of corrosion inhibitors (in $100 \mathrm{~g}$ solution). The commercial product used for comparison in this experiment is made by Shenyang Parkerizing Co., Ltd and its composition is secret and patented.

\subsection{Corrosion and electrochemical test}

Corrosion test is one of the most important methods to evaluate corrosion performance of passivation film [12]. Before the corrosion test, one centimeter of the edge part of samples was sealed. The corrosion test was performed in a saline solution consisting of $5 \% \mathrm{NaCl}$ in a salt spray chamber (NSS test; model:DCTC1200P). The temperature in the injection chamber was approximately $35^{\circ} \mathrm{C}$ and the deposition rate was 1.5 to $2.0 \mathrm{~mL} / \mathrm{h}$. The samples were placed in a vertical direction with the salt spray frame between 15 and 30 degrees. When the samples were evaluated after $72 \mathrm{~h}$ and $96 \mathrm{~h}$, corrosion area was measured in $3 \mathrm{~mm} \times 3 \mathrm{~mm}$ gridding.

Electrochemical experiments were performed in a saline solution consisting of $3.5 \% \mathrm{NaCl}$ at room temperature [13]. Measurements were carried out using a CHI-660 type electrochemical workstation (Shanghai Chen Hua) connected to a three-electrode flat cell. A saturated calomel electrode (SCE) and a platinum electrode were used as the reference electrode and counter electrode, respectively. The working electrode had an exposed area of $1 \mathrm{~cm}^{2}$. The scanning range was between $-1.6 \mathrm{~V}$ and $-0.6 \mathrm{~V}$ and the scanning speed was $0.005 \mathrm{~V} / \mathrm{s}$. The corrosion current and corrosion potential of the samples were determined from the cathodic and anode Tafel potential $[14,15]$.

\subsection{Surface analyzes}

SEM was performed with a SSX-550 microscope (Shimadzu Corporation). The resolution was $3.5 \mathrm{~nm}(30 \mathrm{kv})$ and the enlargement factor was between 20 and 300000 . The accelerating voltage was between 0.5 and $30 \mathrm{kV}$. The microscope was equipped with an energy dispersive spectrometer (EDS) and was used to study the passivation film microstructure, corrosion products morphology, and morphology of the matrix after corrosion. The chemical composition at some representative points was analyzed. Xray photoelectron spectroscopy (XPS) of Kratos-Axis was made from British. The working exposed area was $1 \mathrm{~cm}^{2}$. The spectrum scanning range was between 0 and $1200 \mathrm{eV}$, with a scanning interval of $1 \mathrm{eV}$, and a narrow scanning spacing of $0.1 \mathrm{eV}$. Fourier transform infrared reflection absorption spectroscopy (FTIR) was carried out on a spectrometer produced by American Bio-Rad company. The projection wavelength ranged between 680 and $4800 \mathrm{~nm}$, and the reflection wavelength ranged between 700 and $2500 \mathrm{~nm}$. By analyzing the microstructure of the passivation film, the passivation mechanism can be understood easily.

\section{RESULTS AND DISCUSSION}

\subsection{Corrosion test}

The properties of the different films were all checked using an industrial and traditional test including the exposure to the salt spray chamber. Fig. 1 gives the images that show the corrosion effect of the different films after $24 \mathrm{~h}, 72 \mathrm{~h}, 96 \mathrm{~h}$ of exposure.

The images indicate that the HDG steel after $24 \mathrm{~h}$ of exposure is completely deteriorated and the surface is fully covered by a great amount of white rust (zinc corrosion products). The product film shows that the corrosion area accounts for approximately $32 \%$ of the total surface area. The passivation film with corrosion inhibitors presents a small amount of corrosion area on the sample surface after $96 \mathrm{~h}$ of exposure, which the corrosion area only occupies approximately $3 \%$ of the total surface area that have reached industrial requirements standard. The sample treated with corrosion inhibitors presents much better barrier protection against the serious corrosion on the surface. The reasons of corrosion resistance were investigated by following the SEM, XPS and FTIR so that we can understand the forming mechanism better.

\subsection{Electrochemical test}

The Tafel polarization curves of the different passivation films and the corresponding parameters are shown in Fig. 2 and Table 2, respectively.

Table1. Name and features of the studied samples

\begin{tabular}{|c|c|c|c|c|c|c|}
\hline Name of the sample & AEO-7 & 1788 & $\mathrm{~K}-12$ & Heat & Time & Coating \\
\hline Corrosion inhibitor & $0.2 \mathrm{~g}$ & 0.15 & $0.05 \mathrm{~g}$ & $150{ }^{\circ} \mathrm{C}$ & $60 \mathrm{~s}$ & Rolling \\
\hline No corrosion inhibitor & - & - & - & $150{ }^{\circ} \mathrm{C}$ & $60 \mathrm{~s}$ & Rolling \\
\hline Product film & - & - & - & $150{ }^{\circ} \mathrm{C}$ & $60 \mathrm{~s}$ & Rolling \\
\hline Untread & - & - & - & - & - & - \\
\hline
\end{tabular}




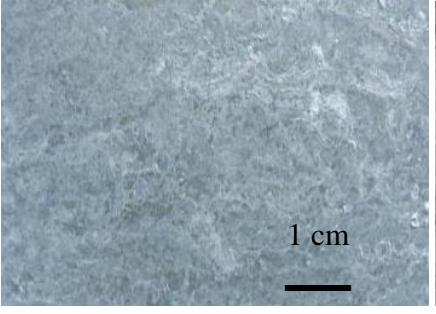

a

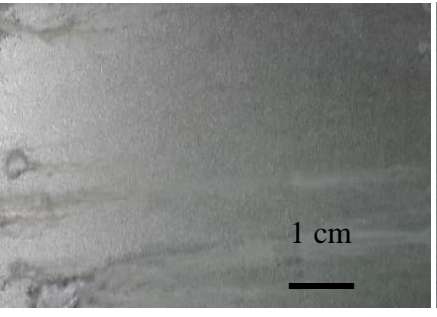

b

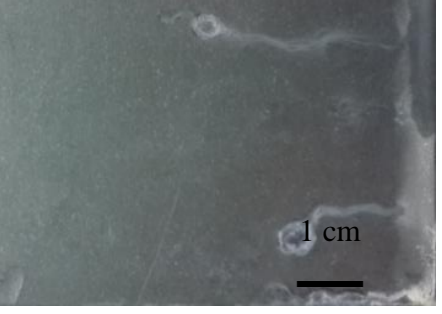

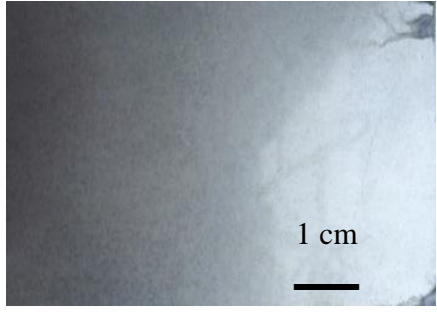

d

Fig. 1. Images of after the NSS test. a-the HDG steel after $24 \mathrm{~h}$ of exposure; $\mathrm{b}$-product film after $72 \mathrm{~h}$ of exposure; $\mathrm{c}-$ no corrosion inhibitor film after $72 \mathrm{~h}$ of exposure; $\mathrm{d}$-corrosion inhibitor film after $96 \mathrm{~h}$ of exposure

Table 2. Tafel polarization parameters for different samples

\begin{tabular}{|c|c|c|c|c|}
\hline Name of the sample & Icorr, $10^{-5} \mathrm{~A} / \mathrm{cm}^{2}$ & Ecorr, V & Cathodic slope & Anode slope \\
\hline Corrosion inhibitor & 0.360 & -1.0868 & 2.571 & 2.356 \\
\hline No corrosion inhibitor & 1.001 & -1.1511 & 2.444 & 2.356 \\
\hline Product & 1.417 & -1.1012 & 3.202 & 2.567 \\
\hline Untreated & 21.761 & -1.0488 & 3.053 & 2.480 \\
\hline
\end{tabular}

The corrosion resistance of the passivation films was determined from the magnitude of the corrosion current density in the conductive solution $(3.5 \%$ wt. $\% \mathrm{NaCl})$. The corrosion resistance of the passivation film without corrosion inhibitor and product film were improved with a factor of two orders from $21.761 \cdot 10^{-5} \mathrm{~A} / \mathrm{cm}^{2}$ of untreated sample to $1.417 \cdot 10^{-5} \mathrm{~A} / \mathrm{cm}^{2}$ of product film.

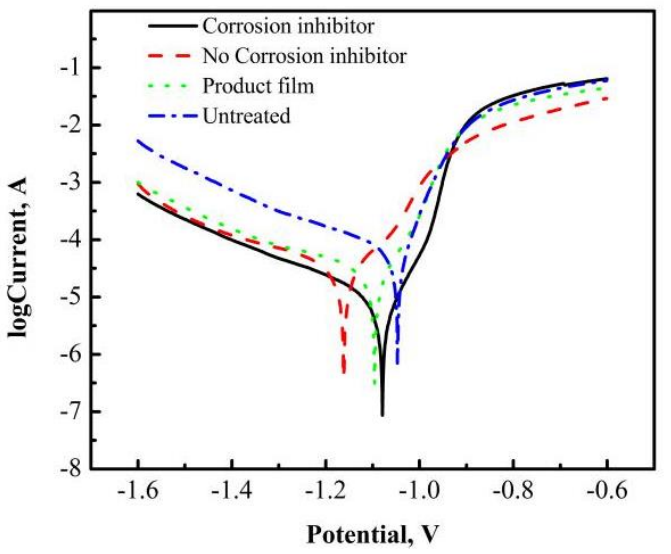

Fig. 2. Tafel polarization curve of different samples

The passivation film without corrosion inhibitor presents similar corrosion resistance with the product film. Obvious differences were observable between passivation film with corrosion inhibitors and the untreated sample. Corrosion current density of the untreated galvanized steel

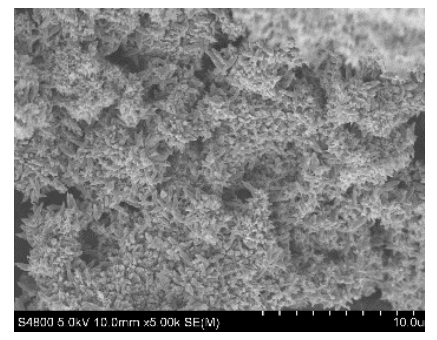

a

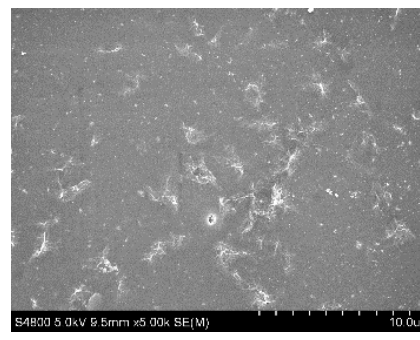

$\mathrm{b}$

was the biggest. With the passivation film with corrosion inhibitors had the smallest corrosion current density, the corrosion resistance of the passivation film with corrosion inhibitors is significantly improved with a factor of about three orders than that of untreated sample from $21.761 \cdot 10^{-5} \mathrm{~A} / \mathrm{cm}^{2}$ of untreated sample to $0.36 \cdot 10^{-5} \mathrm{~A} / \mathrm{cm}^{2}$ of treated sample with corrosion inhibitors. The sample with corrosion inhibitors lead to a fantastic barrier properties. The results of electrochemical measurements were consistent with NSS test. The passivation film with corrosion inhibitors can effectively prevent the entry of corrosive substances into the substrate and trigger the chemical corrosion reaction.

\subsection{Surface analyzes}

In order to obtain more detailed surface morphology information, the corrosion morphology of the untreated sample (Fig. 3 a), product film (Fig. 3 b), the passivation film without corrosion inhibitors (Fig. $3 \mathrm{c}$ ), the passivation film with corrosion inhibitors (Fig. $3 \mathrm{~d}$ ) was investigated after NSS test.

Fig. $3 \mathrm{~d}$ shows that the surface of corrosion inhibitoradded-sample after $96 \mathrm{~h}$ of exposure is compact and uniform, no cracks and other defects than other samples. The untreated sample was completely wrecked and product film had small amount of white rust on the surface. The three different passivation films seem to quite homogeneous and there are small white rust presented in tiny little bits.

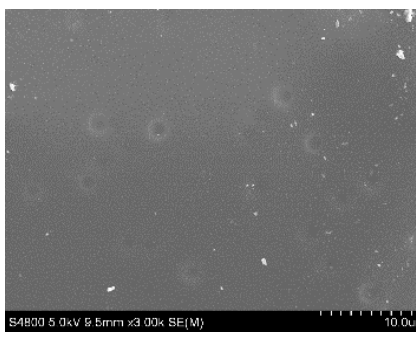

$\mathrm{c}$

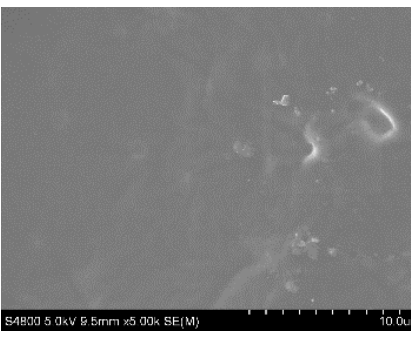

d

Fig. 3. SEM morphology of different samples after NSS test. a - the HDG steel after $24 \mathrm{~h}$ of exposure; $\mathrm{b}$ - product film after $72 \mathrm{~h}$ of exposure; $\mathrm{c}-$ no corrosion inhibitor film after $72 \mathrm{~h}$ of exposure; $\mathrm{d}$-corrosion inhibitor film after $96 \mathrm{~h}$ of exposure 
In Fig. 3 d, we observe that there seems to be a transparent thin layer covering the surface of the white rust.

When corrosion happens, it can be that the corrosion region is refilled by corrosion inhibitors to intend to reshape a transparent thin layer covering the surface of the white rust. Therefore, the corrosion resistance in this film with corrosion inhibitors is relatively excellent. Fig. 4 shows EDS energy spectrum and the element analysis results of corrosion inhibitor film after the $96 \mathrm{~h}$ NSS test. Fig. $4 \mathrm{a}$ and b show the SEM of the gray relative slight corrosion zone and white relative serious corrosion zone of the passivation sample with corrosion inhibitors, respectively. Fig. $4 \mathrm{c}$ depicts weight ratio of various elements comparing different region. As can be seen from Fig. 4 c, the content of carbon in gray area is higher and zinc is relatively lower than that of the white area, indicating that the gray region in the passivation film is much thicker than that of the white area. Due to that the hot galvanized surface is uneven, these lowlying areas accumulate relatively more passivation solution and form a relatively thick passivation film. Fundamentally, being corroded primitively in raised parts (later white area), it is why the massive pitting appear on the surface.

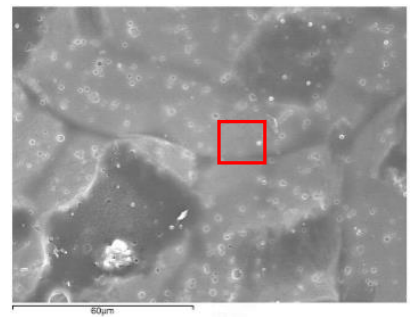

a

c

b

(avea
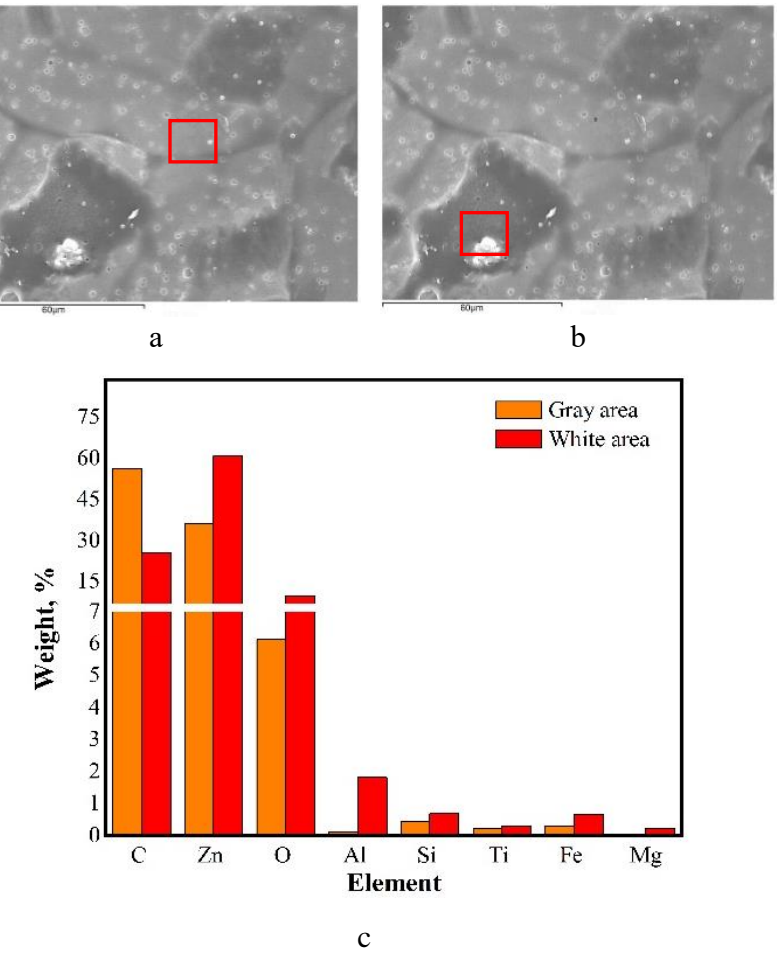

Fig. 4. The SEM analysis after the $96 \mathrm{~h}$ NSS test. a-gray areas energy spectra; b-white areas energy spectra and; $\mathrm{c}$ - weight ratio of various elements, after the $96 \mathrm{~h} \mathrm{NSS}$ test

The content of silicon in gray area is more or less the same as white area, which indicates the silane forming structure is not directly destroyed in white area. But the film formed by resin passivation is seriously deteriorated by observing dramatically different content of carbon in Fig. 4 c. In order to further analyze the chemical bonding states of main elements in the composite passivation film with corrosion inhibitors, four main elements of $\mathrm{C}, \mathrm{Si}, \mathrm{O}$, and $\mathrm{Zn}$ was carried out over a narrow range by $\mathrm{X}$-ray photoelectron spectroscopy (XPS), and the results are shown in Fig. 5.
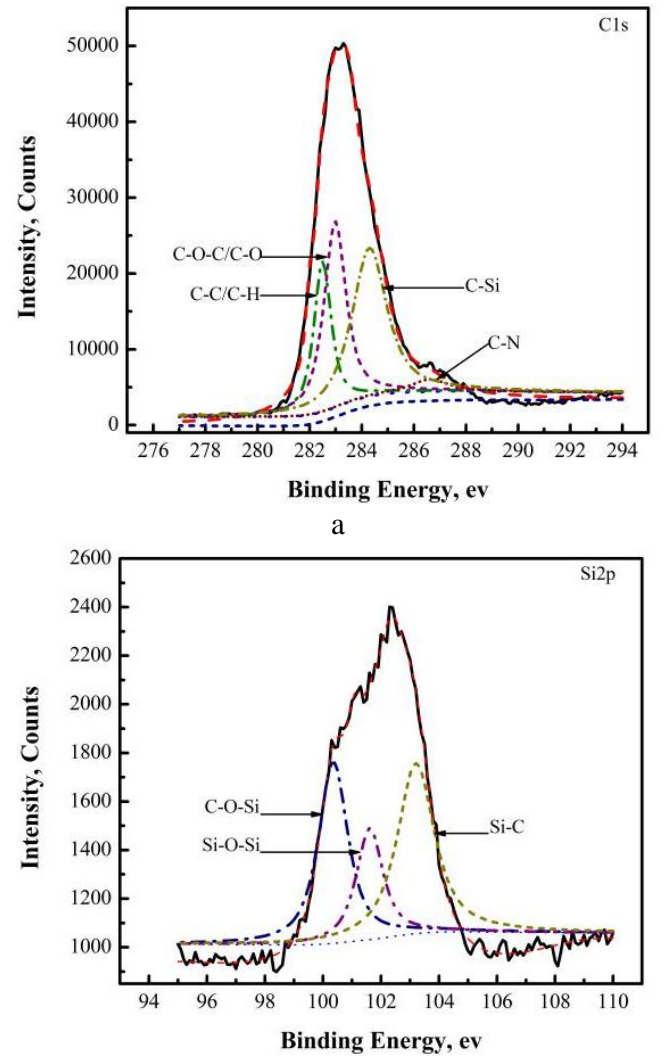

$\mathrm{b}$
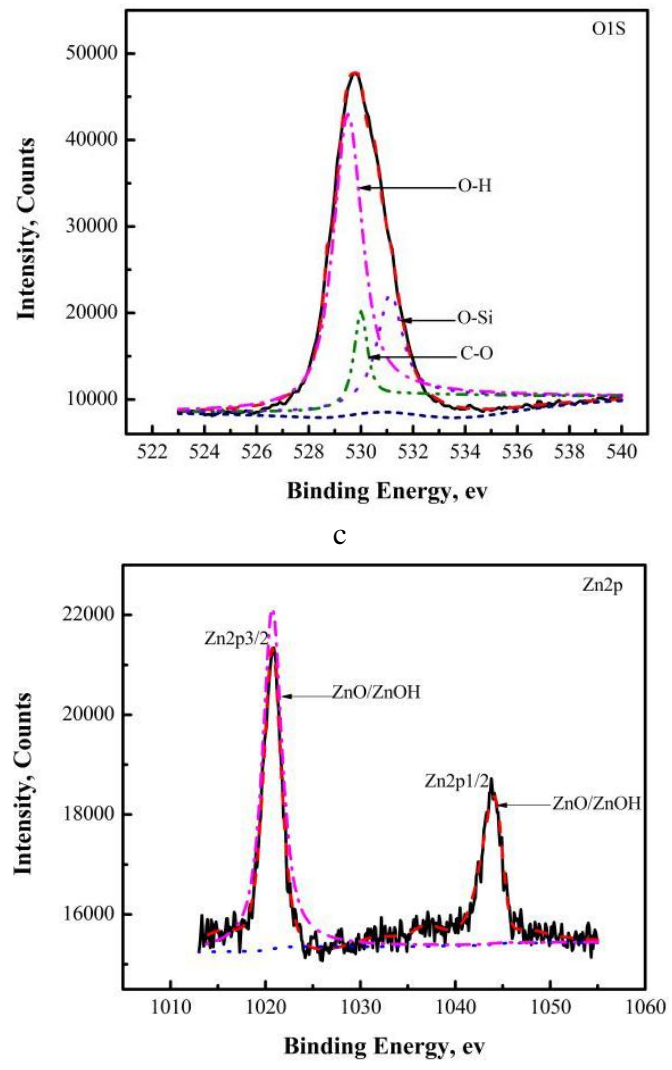

d

Fig. 5. Narrow scan XPS survey spectra of four main elements

Fig. 5 a shows the scanning spectra of $\mathrm{C}$ for the sample. The C1s peak was curve-fitted into four different peaks and compared with the NIST (National Institute of Standards 
and Technology) database. The most obvious peak at a binding energy of $284.80 \mathrm{eV}$ corresponded to C-O-C or C$\mathrm{O}$. The medium intensity peak was the result of the reaction between $\mathrm{C}$ and $\mathrm{Si}$. The lowest intensity peak could be attributed to $\mathrm{C}-\mathrm{N}$. The other peak could be attributed to the reaction of $\mathrm{C}-\mathrm{C}$ or $\mathrm{C}-\mathrm{H}$, according to the NIST database.

The scanning spectra of $\mathrm{Si}$ is displayed in Fig. 5 b. As per the NIST database, the most intense peak in the Si2p spectrum corresponds to $\mathrm{C}-\mathrm{O}-\mathrm{Si}$. The other peaks could be attributed to $\mathrm{Si}-\mathrm{C}$ and $\mathrm{Si}-\mathrm{O}-\mathrm{Si}$, as shown in the figure. The presence of these peaks indicate the formation of a silicone structure as a result of the polymerization reaction between the silicon alcohol in the composite passivation film $[16,17]$.

The Ols signal was curve-fitted into three different peaks, as shown in Fig. 5. c. Based on the NIST database, we conclude that the three different peaks correspond to $\mathrm{C}$ $\mathrm{O}, \mathrm{O}-\mathrm{H}$, and $\mathrm{O}-\mathrm{Si}$. The structures can be mainly derive from the silane and resin. In Fig. 5 d, two peaks can be observed in the $\mathrm{Zn} 2 \mathrm{p}$ spectrum. The $\mathrm{Zn} 2 \mathrm{p} 3 / 2$ and $\mathrm{Zn} 2 \mathrm{p} 1 / 2$ peaks at $1021.9 \mathrm{eV}$ and $1044.6 \mathrm{eV}$, respectively, can be associated to $\mathrm{ZnO}$ and $\mathrm{Zn}(\mathrm{OH})_{2}$, respectively [18].

Fig. 6 shows FTIR of the composite passivation film with corrosion inhibitors. The peak at $3430 \mathrm{~cm}^{-1}$ is a characteristic absorption peak of hydrogen bonding of $-\mathrm{OH}$, which indicates that $\mathrm{Si}-\mathrm{OH}$ was not completely associated with the surface of the metal. The peak at $2922 \mathrm{~cm}^{-1}$ corresponds to the $-\mathrm{CH}_{2}$ and $-\mathrm{CH}_{3}$ stretching vibrations, and the peak corresponding to $\mathrm{N}-\mathrm{H}$ appears at $1550 \mathrm{~cm}^{-1}$ and $1650 \mathrm{~cm}^{-1}$. What's more, the absorption peak at $1624 \mathrm{~cm}^{-1}$ can be the N-H in Fig. 7.

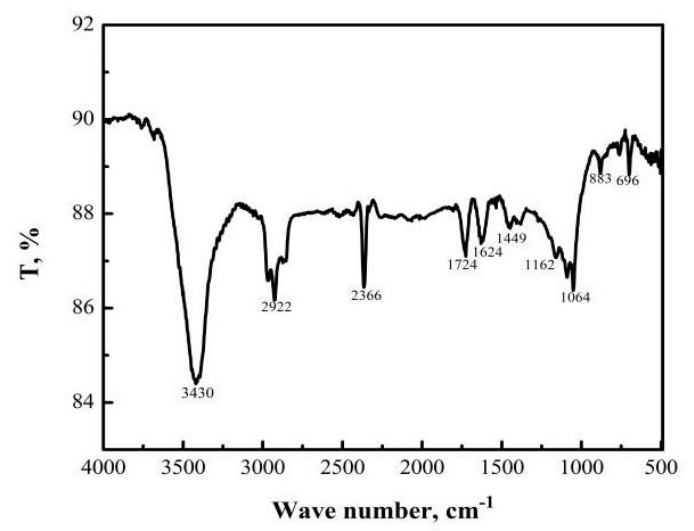

Fig. 6. FTIR of the passivation film with corrosion inhibitors

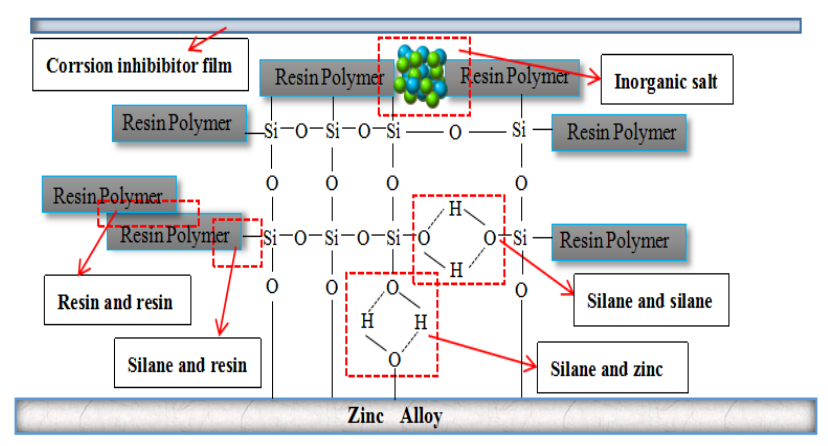

Fig. 7. The forming process of passivation film with corrosion inhibitors
The peaks at $1724 \mathrm{~cm}^{-1}$ and $1449 \mathrm{~cm}^{-1}$ belong to characteristic stretching vibrations of $\mathrm{C}=\mathrm{O}$ and bending vibrations of $-\mathrm{CH}_{2}$, respectively. Furthermore. The peaks at $1064 \mathrm{~cm}^{-1}$ and $1162 \mathrm{~cm}^{-1}$ are considered characteristic stretching vibrations of Si-O. The peaks at $696 \mathrm{~cm}^{-1}$ and 883 $\mathrm{cm}^{-1}$ could be attributed to benzene. Above the surface functional groups also further showed that the passivation film contained the some groups: $-\mathrm{OH}, \mathrm{N}-\mathrm{H},-\mathrm{CH}_{3},-\mathrm{CH}_{2}$, $\mathrm{C}=\mathrm{O}$, Si-O. The peaks at $1064 \mathrm{~cm}^{-1}$ and $1162 \mathrm{~cm}^{-1}$ appear universally, and is believed to be the absorption peaks of $\mathrm{Si}$ $\mathrm{O}-\mathrm{Si}$ and $\mathrm{Si}-\mathrm{O}-\mathrm{Zn}$, as per previous reports [19].

All of these analysis such as SEM, EDS, XPS, FTIR results demonstrate the forming process of the passivation film with corrosion inhibitors on Hot-Dip Galvanized steel surface should consist of multiple reaction. The schematic diagram is shown in Fig. 7.

Firstly, sufficient numbers of active $\mathrm{Si}-\mathrm{OH}$ groups are generated by hydrolysis reaction in the solution [20] according to Eq. 1.

$$
\mathrm{R}-\mathrm{Si}\left(\mathrm{OCH}_{3}\right)_{3}+3 \mathrm{H}_{2} \mathrm{O} \rightarrow \mathrm{R}-\mathrm{Si}(\mathrm{OH})_{3}+3 \mathrm{CH}_{3} \mathrm{OH} ;
$$

The next step is extremely important because the reaction of both silane and silane, silane and resin, resin and resin, silane and zinc is regarded as the cardinal structure of passivation film as described in Eq. 2 -Eq. 4.

$$
\begin{aligned}
& \mathrm{Si}-\mathrm{OH}+\mathrm{Si}-\mathrm{OH} \rightarrow \mathrm{Si}-\mathrm{O}-\mathrm{Si}+\mathrm{H}_{2} \mathrm{O} \\
& \mathrm{Si}-\mathrm{OH}+\mathrm{Zn}-\mathrm{OH} \rightarrow \mathrm{Si}-\mathrm{O}-\mathrm{Zn}+\mathrm{H}_{2} \mathrm{O} \\
& \left(\mathrm{C}_{11} \mathrm{H}_{12} \mathrm{O}_{2}\right)_{\mathrm{n}}+\mathrm{Si}-\mathrm{OH} \rightarrow\left(\mathrm{C}_{11} \mathrm{H}_{12} \mathrm{O}_{2} \mathrm{Si}\right)_{\mathrm{n}}+\mathrm{nH}_{2} \mathrm{O} .
\end{aligned}
$$

The network formed by several kind of reaction probably lead to the formation of a reticulated passivation film on the surface of the Hot-Dip Galvanized steel. The high degree of intermolecular bounds ( $\mathrm{Si}-\mathrm{O}-\mathrm{Si}$ and $\mathrm{Si}-\mathrm{O}-\mathrm{Zn}$ ) lead to the formation of a film with considerable barrier properties. What' more, the inorganic salt $(\mathrm{Ti}, \mathrm{V})$ is released and padded the interstice of forming passivation film to enhance corrosion resistance. Finally, the corrosion inhibitors shown in Fig. 7 form a transparent thin layer covering the top of passivation film. It is a fact that the forming of a compact reticulated structure and a transparent thin layer probably is main reason why this system gives the best results.

\section{CONCLUSIONS}

In order to solve the toxicity and pollution problem associated with the use of hexavalent chromium, there is a need to replace currently used chromate-based passivation technology. In this paper, the use of an organic and inorganic passivation film with corrosion inhibitors was discussed and studied in detail.

The passivation film with corrosion inhibitors affords favorable corrosion resistance in contrast to another passivation films. After a $96 \mathrm{~h}$ corrosion test, the corrosion rate of the passivation film with corrosion inhibitors was significantly reduced with a factor of about three orders compared with the film of untreated sample, which indicated that the chromate-free composite passivation with inhibitors presented an excellent corrosion 
resistance and reached the requirements of some industrial products.

SEM, EDS, XPS, and FTIR tests showed unambiguously the formation of an organic and inorganic passivation film with corrosion inhibitors. This passivation film was found to be so dense and uniform that it greatly improved the corrosion resistance of the hot-dip galvanized steel.

\section{REFERENCES}

1. Deflorian, F., Rossi, S., $\quad$ Fedel, M., $\quad$ Motte, C. Electrochemical Envestigation of High-Performance Silane Sol-gel Films Containing Clay Nanoparticles Progress in Organic Coating 69 (2) 2010: pp. 158-166. https://doi.org/10.1016/j.porgcoat.2010.04.007

2. Fedel, M., Olivier, M., Poelman, M., Deflorian, F., Rossi, S., Druart, M.E. Corrosion Protection Properties of Silane Pre-treated Powder Coated Galvanized Steel Progress in Organic Coatings 66 (2) 2009: pp. 118-128. https://doi.org/10.1016/j.porgcoat.2009.06.011

3. Kong, G., Lu, J.T., Zhang, S.H., Che, C.S., Wu, H.J. A Comparative Study of Molybdate/Silane Composite Films on Galvanized Steel with Different Treatment Processes Surface and Coatings Technology 205 (2) 2010: pp. $545-550$. https://doi.org/10.1016/j.surfcoat.2010.07.033

4. Koltsov, A., Cornu, M.J., Loison, D. Characterization by Different Analytical Techniques of $\mathrm{SiO}_{2}$ and Silane Thin Films Deposited on Rough Hot-dip Galvanized Steel Surfaces Surface and Coatings Technology 206 (11-12) 2012: pp. 2759-2768. https://doi.org/10.1016/j.surfcoat.2011.11.027

5. Zhu, D.Q., van Ooij, W.J. Enhanced CorrosionResistance of AA 2024-T3 and Hot-dip Galvanized Steel Using A Mixture of Bis-[trithoxysilylpropyl]tetrasulfide and Bistrithoxysilylpropyl]amine Electrochimica Acta 49 (7) 2004: pp. $1113-1125$. https://doi.org/10.1016/j.electacta.2003.10.023

6. Fedel, M., Druart, M.E., Oliver, M., Poelman, M., Deflorian, F., Rossi, S. Compatibility between Cataphoretic Electro-coating and Silane Surface Layer for the Corrosion Protection of Galvanized Steel Progress in Organic Coatings 69 (2) 2010: pp. 118-125. https://doi.org/10.1016/j.porgcoat.2010.04.003

7. Oliver, M.G., Fedel, M., Sciamanna, V., Vandermiers, C., Motte, C., Poelman, M., Deflorian, F. Study of the Effect of Nanoclay Incorporation on the Rheological Properties and Corrosion Protection by A Silane Layer Progress in Organic coatings $72(1-2)$ 2011: pp. 15-20. https://doi.org/10.1016/j.porgcoat.2010.11.022

8. Zandi-zand, R., Ershad-langroudi, A., Rahimi, A. Silica Based Organic-inorganic Hybrid Nanocomposite Coatings for Corrosion Protection Progress in Organic Coatings 53 2005: pp. $286-291$. https://doi.org/10.1016/j.porgcoat.2005.03.009

9. Xiao, W., Man, R.L., Miao, C., Peng, T.L. Study on Corrosion Resistance of the BTESPT silane Cooperating with Rare Earth Cerium on the Surface of Aluminum-tube Journal of Earths 28 (1) 2010: pp. 117-122. https://doi.org/10.1016/S1002-0721(09)60063-6

10. Metroke, T.L., $\quad$ Kachurina, O., $\quad$ Knobbe, E.T.
Spectroscopic and Corrosion Resistance Characterization of Amine and Super Acid-cured Hybrid Organic-inorganic Thin Films on 2024-T3 Aluminum Alloy Progress in Organic Coatings 44 2002: pp. 185-199.

https://doi.org/10.1016/S0300-9440(02)00007-3

11. Baldin, E.K.K., $\quad$ Kunst, S.R., Beltrami, L.V.R., Lemos, T.M., Quevedo, M.C., Bastos, A.C., Ferreira, M.G.S., Santos, P.R.R., Sarmento, V.H.V., Malfatti, C.F. Ammonium Molybdate Added in Hybrid Films Applied on Tinplate: Effect of the Concentration in the Corrosion Inhibition Action Thin Solid Films 1 2016: pp. 146-156.

https://doi.org/10.1016/j.tsf.2016.01.034

12. Bierwagen, G., Tallman, D., Li, J.P. EIS Studies of Coated Metals in Accelerated Exposure Progress in Organic Coatings $46(2)$ 2003: pp. 148-157.

13. Barranco, V., Feliu, Jr.S., Feliu, S. EIS Study of the Corrosion Behaviour of Zinc-based Coatings on Steel in Quiescent 3\% NaCl Solution. Part 1: Directly Exposed Coatings Corrosion Science 46 (9) 2004: pp. 2203-2220. https://doi.org/10.1016/j.corsci.2003.09.032

14. El-Sayed, A.R., $\quad$ Shaker, A.M., $\quad$ El-Lateef, H.M.A. Corrosion Inhibition of Tin, Indium and Tin-indium Alloys by Adenine or Adenosine in Hydrochloric Acid Solution Corrosion Science 52 (1) 2010: pp. $72-81$. https://doi.org/10.1016/j.corsci.2009.08.047

15. El-Sayed, A.R., Harm, U., Mangold, K.M., Fürbeth, W. Protection of Galvanized Steel from Corrosion in $\mathrm{NaCl}$ Solution by Coverage with Phytic acid SAM Modified with Some Cations and Thiols Corrosion Science 55 2012: pp. 339-350. https://doi.org/10.1016/j.corsci.2011.10.036

16. Jiang, L., Wolpers, M., Volovitch, P., Ogle, K. An Atomic Emission Spectroelectrochemical Study of Passive Film Formation and Dissolution on Galvanized Steel Treated with Silicate Conversion Coatings Surface and Coatings Technology 206 2012: pp. 3151-3157. https://doi.org/10.1016/j.surfcoat.2012.01.016

17. Yuan, M.R., Lu, J.T., Kong, G., Chen, C.S. Self Healing Ability of Silicate Conversion Coatings on Hot Dip Galvanized Steels Surface and Coatings Technology 205 2011: pp. $4507-4513$. https://doi.org/10.1016/j.surfcoat.2011.03.088

18. Montemor, M.F., Simões, A.M., Ferreira, M.G.S., Williams, B., Edwards, H. The Corrosion Performance of Organosilane Based Pre-treatments for Coatings on Galvanised Steel Progress in Organic Coatings 38 (1) 2000: pp. $17-26$. https://doi.org/10.1016/S0300-9440(99)00080-6

19. Beccaria, A.M., Chiaruttini, L. The Inhibitive Action of Metacryloxypropylmethoxysilane(MAOS) on Aluminum Corrosion in $\mathrm{NaCl}$ Solutions Corrosion Science 41 (5) 1999: pp. $885-899$. https://doi.org/10.1016/S0010-938X(98)00161-9

20. Wang, L., Liu, C.S., Yu, H.Y., An, C.Q. Structure and Corrosion Resistance of a Composite $\gamma$-Amino Propyl Triethoxy Silane and $\gamma$-Glycidoxy Propyl Trimethoxy Silane Conversion Coating on Galvanized Steel Journal of Iron and Steel Research 19 (11) 2012: pp. 46-51. https://doi.org/10.1016/S1006-706X(13)60019-9 